\title{
Envy, Personality's Riskiness and Methods for Achieving of High Economic Status
}

\author{
Rail M. Shamionov \\ Department of Psychological, Pedagogical and Special Education, Saratov State University, Saratov, Russia \\ Email: shamionov@mail.ru
}

Received January 2014

\begin{abstract}
The major research objective is to study of ratio of envy with acceptability of methods (tools) for achieving high economic status and riskiness of personal. This research was carried out with 164 respondents (39\% of them were men). The results show higher allow ability of using illegal methods for achieving economic prosperity, i.e. tax evasion, delinquency in paying child support or transportation fares. The behavioral realm is dominated by risk, but attitudes of personality more often exclude risky activity in the material sphere. Correlation studies confirm the hypothesis about the selective risky activity of an envious personality.
\end{abstract}

\section{Keywords}

Personality, Envy, Risk

\section{Introduction}

For a long time envy has been seen as an ethical problem. However, study of the origins of personal envy has frequently become the subject of interest for psychologists. In the study of W. Mc Dougall [1], that was written over a century ago, the idea that formation of a personality is closely associated with admiration (surprise and bad health), as admiration makes a child more susceptible to influence of other people. In order for something to become property of the identity (in particular, moral views), it is necessary to have not only surprising, but negative feelings as well, which puts it in a subordinate situation. In other words, the basis for the formation of envy can be found in the early mechanisms of personality's development. Envy is not associated with it directly, but rather indirectly, through the fixation of negative feelings.

According to T.V. Beskova, "envy is a hostile attitude towards another, determined by his superiority in important areas, accompanied by negative emotions and manifested through the desire to deprive him, directly or indirectly, of this superiority” [2, p. 22]. Enviousness is formed in the process of socialization and can probably be submitted early enough in relation to the particular social conditions of children's development [3].

The main socio-psychological mechanisms of formation of envy are comparing and evaluating [4]-[7]. As a result of comparison they are updated in a new form. Studies of V.A. Labunskaja show that there are at least two main reasons for comparing and evaluating to cause envy_orientation towards "leveling" and frustration of a need in confirmation on the part of those who cause envy [8, p. 129]. However, there is evidence, that behavioral effect of envy may be blocked because of social congruence and pro-sociality of a personality [7]. Moreover, 
there are attempts to find something positive in envy—studies on benign and malicious envy [2]-[4] [7].

Under conditions of competition in different areas of social life, envy can become a factor of its increase as well as decrease due to destructive impact on the "superiority spheres"-it happens both directly and indirectly.

Therefore, the purpose of our empirical research was the study of ratio of envy with acceptability of methods (tools) for achieving high economic status and strategy of individual activity.

\section{Methodology of Research}

\subsection{General Background of Research}

Hypothesis. The main hypothesis of this study is that there are similarities and differences between belief in the validity of various ways to improve the economic status of a person, readiness for a risky activity in various areas in people with high and low levels of envy, and that there is a correlation between envy and strategy of the activity.

This study is conducted on the basis of methodology for systematic and structured approach in psychology. In accordance with the purpose and basic approach, the study is carried out with correlation and comparison survey method.

\subsection{Participants}

This study examined the sample of 100 females and 64 males over 20 years old (39\% of them males). The mean sample of age is 30.13 years old $(\mathrm{SD}=11.32)$.

\subsection{Instruments}

The techniques. The Beskova's scales of indirect estimation of envy imply measurement (from 1 to 5 ) of envy depending on the superiority of another person ("The physical excellence materiel supremacy", "Social excellence”, “Intelligential excellence”, “Excellence of personal’s characteristics”, “Excellence in family’s life”); used scale: 1-never envious; 2-mainly not envious; 3-hard to say; 4-envious; 5-very envious (Beskova, 2010).

Beskova's technique for studying personal enviousness (47 items) consists of 4 scales: integral estimation of envy (32 items; maximum score-128), envy-antipathy (17 items; maximum score-68), envy-dejection (15 items; maximum score-60), masking envy (15 items; maximum score-60). Items are priced according to the 5-point scale (0—completely disagree, 4—completely agree) [9].

Schubert's method of evaluation of the readiness to take risks in Raygorodskiy's edition consists of 25 items. Items are rated according to a 5-point scale (from +2 to -2 totally agree-strongly disagree); maximum score is 50 points [10].

The next block of questions was designed to detect the framework for the use of legal and illegal methods of achieving economic well-being. 5-point system of evaluation was offered (1-Yes; 5-No, in no case) in order to find out whether, in their opinion, it is acceptable: "Utilization of illegal methods", "Unskilled work for money”, "Bribing an official”, "Work during anti-social hours (additional work)”, "Evasion from paying child support”, "Reselling goods with a substantial retail margin”, "Fare evasion”, "Working for a private entrepreneur”, “Tax evasion Preference to interesting work”. The next block of questions concerns such attitudes as risk (e.g. "when making a decision where would you prefer not to risk?” “... in relationships with friends”, “... in financial issues”, “... concerns their health”, “... in relations with management”, “... in property issues”).

Next, respondents were asked to rate (from 1 to 5 points) behavioral tendencies in situations threatening well-being (in financial issues, at work, at home, health-connected): 1) to take some time out, 2) to take immediate measures, despite the risks, 3) to take action only after making sure there are no risks, 4) put up with the situation, 5) to change one's way of life.

\section{Results and Discussion}

The examination of the acceptability of methods (tools) for achieving high economic status of respondents helped to obtain data that shows apparent trends of acceptability of illegal means in envious persons (Table 1).

People with high levels of envy, believe that it is possible to use illegal methods. However, they are showing 
Table 1. Evidence indicators showing inadmissibility of ways of improving economic situation and riskiness in persons with high and low levels of envy.

\begin{tabular}{ccccccc}
\hline & \multicolumn{2}{c}{ Envious } & \multicolumn{2}{c}{ Non-envious } & \multicolumn{2}{c}{ t-test for equality of means } \\
\hline & $\mathrm{M}$ & $\mathrm{SD}$ & $\mathrm{M}$ & $\mathrm{SD}$ & $\mathrm{t}$ & Sig. (2-tailed) \\
\hline Utilization of illegal methods & 2.86 & 1.31 & 4.73 & 0.59 & 4.56 & 0.01 \\
Utilization of illegal methods & 2.86 & 1.31 & 4.73 & 0.59 & 4.56 & 0.01 \\
Unskilled work for money & 2.71 & 1.40 & 3.47 & 1.45 & 1.52 & 0.14 \\
Bribing an official & 3.00 & 1.00 & 3.80 & 1.14 & 1.01 & 0.32 \\
Work during anti-social hours (additional work) & 2.86 & 1.04 & 2.20 & 0.86 & 0.03 & 0.97 \\
Evasion from paying child support & 3.28 & 1.36 & 4.80 & 0.56 & 1.89 & 0.05 \\
Reselling goods with a substantial retail margin & 3.29 & 0.80 & 4.67 & 0.61 & 4.50 & 0.01 \\
Fare evasion & 3.42 & 1.21 & 4.60 & 1.05 & 2.23 & 0.01 \\
Working for a private entrepreneur & 3.00 & 1.14 & 3.40 & 1.50 & 0.34 & 0.73 \\
Tax evasion & 3.28 & 1.34 & 4.87 & .51 & 2.29 & 0.03 \\
Preference to interesting work & 3.47 & 1.23 & 2.26 & 1.38 & 2.58 & 0.01 \\
Riskiness & 1.29 & 12.29 & -9.81 & 15.6. & 2.26 & 0.03 \\
\hline
\end{tabular}

Note: The reversed scale is used (1-Yes, no doubt, 5—no, in no case).

enterprise, considering trade with a substantial retail margin to the purchased goods acceptable. They consider fare evasion, tax evasion and evasion from paying child support possible. Individuals with low levels of enviousness demonstrate more inclination to do low-paid but interesting work.

This data is confirmed by the results of correlation analysis. Thus, the validity of tax evasion is associated with envy to the physical $(\mathrm{r}=-0.40, \mathrm{p}<0.01)$ and material $(\mathrm{r}=-0.27, \mathrm{p}<0.01)$ superiority in the sphere of family life $(\mathrm{r}=-0.29, \mathrm{p}<0.01)$; fare evasion is associated with social $(\mathrm{r}=-0.24, \mathrm{p}<0.05)$ and material superiority $(\mathrm{r}=$ -0.26 , $\mathrm{p}<0.01)$; possibility of bribery — with envy to social $(\mathrm{r}=-0.25, \mathrm{p}<0.01)$ and material superiority $(\mathrm{r}=$ $-0.26, \mathrm{p}<0.01)$.

This data is somewhat consistent with the results of the study by K. Muzdybaev [11] which shows that the envious are confident that various forms of conduct that violate the laws and morality are acceptable. Unlike the envious, the non-envious people tend to work overtime and even do unskilled work in order to achieve higher material status and consider breaking of norms of law and morality unacceptable.

From this data it follows that, in fact, the envious possess more attitude and rules for their own conduct, admitting illegal behavior in the economic sphere. Perhaps they are projected on the achievements of others: an envious person believes that the other has reached greater material well-being using illegal ways.

Indicators on the Schubert's risk scale demonstrated greater level of riskiness in envious people and prudence in the non-envious people $\left(r_{\text {(risk; } \text { envy) }}=0.20, p<0.05\right)$. However, the envious often prefer not to risk in contrast to the non-envious people when it comes to their finances ( $56.3 \%$ vs. $25.0 \%$ ) and property ( $43.8 \%$ vs. $25.0 \%$ respectively). This suggests that in fact the envious, seeking to better the economic situation, and being less careful, however, are not prepared to take risks in their economic situation, which is clearly a barrier (in a number of other things) to the relevant achievements and readiness for economic modernization. However, separate action, which is even more risky in respect of personal economic achievements in the legal field is not supported. Meanwhile, they are more willing to take risks, if it concerns their health (35.3\% and 50.1\%) and relations with management (5.9\% and 31.3\%).

One of the significant aspects of our study is identification of behavioral patterns in complicated economic and everyday situations in connection with envy. Envy in terms of physical, social superiority, as well as in family life and a cumulative score of envy are associated with the strategy of the activity involving risk (Table 2). However, a cautious strategy of activity (excluding risks) is back connected with envy to social status and material superiority.

Based on the obtained results, we can say that risky activity is increasingly fraught with "social" envy and to a less extent with material envy. Let us note, that risky activity (back) is associated with attitude to material wealth as a result of labor $(r=-0.41, p<0.01)$, which indicates the propensity for risky actions, rejecting the need for painstaking work in order to achieve tangible (monetary) wealth. In other words, risky activity is linked to social 
Table 2. Pearson correlation coefficients between strategy of the activity and characteristics of envy ( $\mathrm{N}=164)$.

\begin{tabular}{ccccccccc}
\hline & $\begin{array}{c}\text { Physical } \\
\text { superiority }\end{array}$ & $\begin{array}{c}\text { Social } \\
\text { superiority }\end{array}$ & $\begin{array}{c}\text { Material } \\
\text { superiority }\end{array}$ & $\begin{array}{c}\text { Intelligential } \\
\text { superiority }\end{array}$ & $\begin{array}{c}\text { Personal } \\
\text { superiority }\end{array}$ & $\begin{array}{c}\text { Superiority } \\
\text { in family life }\end{array}$ & $\begin{array}{c}\text { Envy-antipathy } \\
\text { Envy- } \\
\text { dejection }\end{array}$ \\
\hline $\begin{array}{c}\text { Strategy of the activity } \\
\text { involving risk }\end{array}$ & $0.38^{* *}$ & $0.36^{* *}$ & 0.12 & 0.11 & $0.22^{*}$ & $0.30^{* *}$ & $0.19^{*}$ & 0.02 \\
Cautious strategy of activity & -0.01 & $-0.25^{* *}$ & $-0.24^{*}$ & -0.07 & -0.12 & -0.10 & -0.12 & -0.04 \\
\hline Note: ${ }^{*} \mathrm{p}<0.05 .^{* *} \mathrm{p}<0.01$. & & & & & & & &
\end{tabular}

envy and rejecting the need for labor in order to achieve material prosperity.

\section{Conclusion}

Attitudes of an envious personality are centered around the use of illegal means to achieve economic well-being, risk under conditions of danger and refraining from risky activity on their property (non-envious personality often refuses to risk in relationships with others).

The strategy of risky activity in situations threatening the well-being is envy in social spheres (characteristics of excellence/superiority), presenting the possibility of getting rich, without making any effort and high level of claims for the money as factors of subjective well-being; the strategy of cautious activity involves low level of envy for social success and material superiority.

\section{References}

[1] Mc Dougall, W. (1908) An Introduction to Social Psychology. Methuen \& Co., London, 281 p. http://dx.doi.org/10.1037/12261-000

[2] Beskova, T.V. (2010) The Social Psychology of Envy. Saratov, Nauka, 192 c.

[3] Shamionov, R.M. (2010) The Link “Subjective” Personal Properties and Envy. Izvestiya Saratovskogo Universiteta. Serija Filosofija. Psihologija. Pedagogika, 10, 93-98.

[4] Smith, R.H. and Kim, S.H. (2007) Comprehending Envy. Psychological Bulletin, 133, 46-64. http://dx.doi.org/10.1037/0033-2909.133.1.46

[5] Cohen-Charash, Y. and Mueller, J. (2007) Does Perceived Unfairness Exacerbate or Mitigate Interpersonal Counterproductive Work Behaviors Related to Envy? Journal of applied psychology, 92, 666-680. http://dx.doi.org/10.1037/0021-9010.92.3.666

[6] Yamada, M. and Takahashi, H. (2011) Happiness Is a Matter of Social Comparison. Psychologia, 54, 252-260. http://dx.doi.org/10.2117/psysoc.2011.252

[7] van de Ven, N., Zeelenberg, M. and Pieters, R. (2011) Why Envy Outperforms Admiration. Personality and Social Psychology Bulletin, 37, 784-795. http://dx.doi.org/10.1177/0146167211400421

[8] Labunskaya, V.A. (2005) Zavist', beznadezhnost' i nadeghda kak sposob preobrazovanija bytija subekta. In Lichnost’ i bytie: Subektnyj podhod. Kubanskij Universitet, Krasnodar, 120-137.

[9] Beskova, T.V. (2012) A Technique for Studying Personal Envyousness. Voprosy Psihologii, 2, 127-141.

[10] Rajgorodskij, D.J. (2000) Prakticheskaya psikhodiagnostika. Metodika i testy. Samara, izdatel'skij dom БAXPAX-M, 632-635.

[11] Muzdybaev, K. (2002) Envy of Personality. Psikhologicheskij Zhurnal, 23, 38-51. 